\title{
Ebstein anomaly in the adult: focus on pregnancy
}

\author{
Paraskevi Koutrolou-Sotiropoulou, Fabio V. Lima, Anjali Kapur and Kathleen Stergiopoulos*
}

*Correspondence: Kathleen.Stergiopoulos@stonybrookmedicine.edu

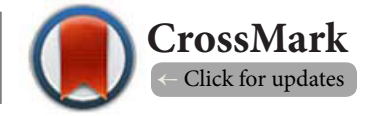

Department of Medicine, Division of Cardiovascular Medicine, State University of New York, Stony Brook, New York.

\begin{abstract}
Ebstein anomaly (EA) is a rare cardiac congenital abnormality characterized by downward displacement of the posterior and septal leaflets of the tricuspid valve which results in atrialization of the right ventricle, enlargement of the right atrium and tricuspid regurgitation. Affected individuals experience a wide spectrum of clinical severity, ranging from heart failure in infants to asymptomatic adults and identification of the disease later in life. Other clinical presentations include cyanosis, arrhythmias and paradoxical emboli through atrial level shunts. Imaging modalities such as echocardiography and cardiac magnetic resonance are used for diagnosis. Appropriate surgical and medical management tailored to each patient's anatomy and hemodynamic status is necessary in order to ensure acceptable patient outcomes. Since most patients survive to childbearing age, understanding of the hemodynamic changes during pregnancy and careful planning of labor and delivery are paramount. The purpose of this review is to focus on Ebstein anomaly in the adult patient tailored for the adult cardiologist and to provide a systematic review of pregnancy outcomes in women with Ebstein anomaly.
\end{abstract}

Keywords: Ebstein anomaly, congenital heart disease, right heart dysfunction, cardiac magnetic resonance imaging, echocardiography, pregnancy, systematic review

\section{Introduction}

In 1866, Dr Wilhelm Ebstein first described the clinical and anatomical features of the congenital anomaly of the tricuspid valve [1]. He described the case of a man who died of cyanotic heart disease secondary to a malformation of the tricuspid valve, which ultimately became known as Ebstein anomaly (EA). Since that time, advances in the diagnosis and management of this disease have been made, many of which will be described herein.

\section{Review}

\section{Epidemiology and genetics}

Ebstein anomaly (EA) is a rare cardiac congenital defect which accounts for less than $1 \%$ of congenital heart disease (CHD) [2]. The prevalence of Ebstein anomaly is estimated at 1 in 200,000 live births [3]. Several genetic and environmental risk factors have been identified, including exposure to benzodiazepines, lithium, cocaine and marijuana [2]. Most cases of Ebstein anomaly are sporadic, although familial cases have been described in the literature [4]. Mutations in several genes encoding sarcomeric proteins have been identified in association with Ebstein anomaly, including cardiac myosin-binding protein $\mathrm{C}$, alpha-cardiac actin, cardiac troponin $\mathrm{T}$ and $\mathrm{I}$, and alpha-tropomyosin. The genetic association with sarcomeric proteins allows for plausibility that Ebstein anomaly is a disease of the myocardium as well as valve tissue [5]. Specifically, an association between Ebstein anomaly and mutation in MYH7. MYH7 mutations are predominantly found in Ebstein anomaly associated with left ventricular noncompaction [6].

\section{Anatomy}

Anatomically Ebstein anomaly is characterized by a functionally and morphologically abnormal tricuspid valve (TV) and right ventricle (RV). Embryologically, the leaflets of the TV develop from the endocardial cushion tissue and the myocardium of the $\mathrm{RV}$ via delamination which is characterized by separation of the tissue from the underlying myocardium during weeks 8 through 12 [7]. In Ebstein anomaly, failure of delamination results in a large anterior tricuspid leaflet, which is usually attached to the tricuspid valve annulus and can be redundant and fenestrated (Figure 1). In normal individuals, displacement of the posterior and septal leaflets of the TV in comparison with the mitral valve leaflet is 8 millimeter per square surface body area or less. In Ebstein anomaly, the posterior and septal leaflets are displaced posteriorly and downward towards the RV. This accounts for 
the "atrialization" of the RV (aRV) and dilation of the tricuspid annulus with resultant tricuspid regurgitation and enlargement of the right atrium (RA). Patients with untreated Ebstein anomaly have large functional right ventricles, as shown in an elegant magnetic resonance imaging (MRI) study [8]. In this study, the size of the enlarged functional right ventricle seemed to depend on the degree of tricuspid regurgitation and not the size of the atrialized right ventricle or the age of the patient. The functional $\mathrm{RV}$ consists mostly of the right ventricular outflow tract and RV apex. The rest of the RV combines with the RA and serves as a passive conduit of blood. Majority of the Ebstein anomaly cases have a dilated RV and RA, with varying degrees of tricuspid annular dilatation. The extent of the TV displacement, RV dilation and TV regurgitation vary from patient to patient, accounting for diversity in the clinical presentation of this anomaly. The dictum "every single heart in Ebstein anomaly is different" [9] has been professed. Table 1 notes the most commonly used classification [10]. Elevated atrial pressures increase the possibility

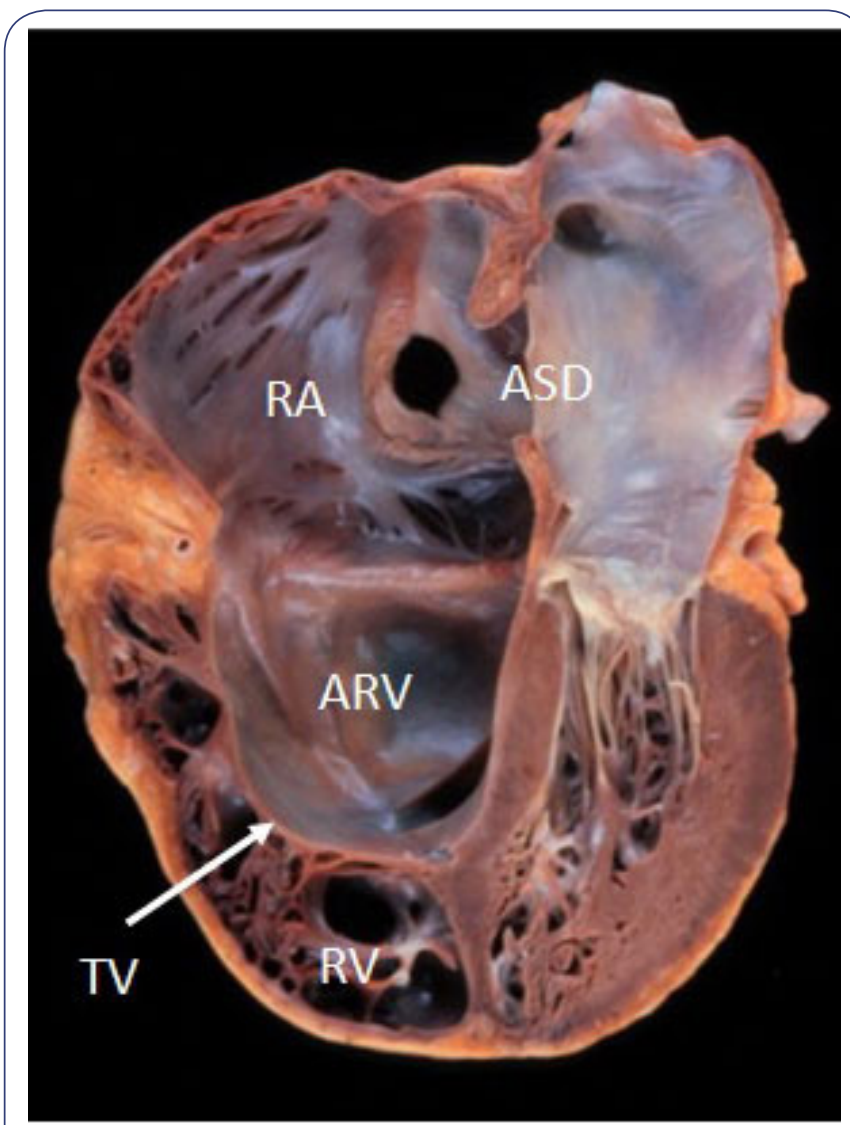

Figure 1. Pathologic specimen from a patient with Ebstein anomaly.

Tricuspid valve is displaced markedly inferiorly and the right ventricular wall is thin. With permission from [59]. Severe right atrial (RA) enlargement, the atrialized right ventricle (ARV), small RV, and the apically displaced tricuspid valve (white arrow, TV) consistent with Ebstein anomaly. A secundum atrial septal defect (ASD) is also present. of a right to left shunt in cases that have a coexistent patent foramen ovale (PFO) or atrial septal defect (ASD). Dilation of the RV may lead to abnormal right ventricular systolic function and clinical heart failure. Concomitant lesions in patients with Ebstein anomaly have been reported [11]. Other cardiac lesions and associations include ventricular septal defect, coarctation of the aorta, pulmonary outflow obstruction and mitral valve prolapse, among others [12] (Table 2).

\section{Clinical presentation and physical examination Physical examination}

In an adult patient with Ebstein anomaly, clinical features that may be presenton physical exam include edema and cyanosis $[13,14]$. An Ebstein patient may have a holosystolic murmur associated with tricuspid regurgitation. A widely split S1 heart sound can be heard with a loud tricuspid component resulting from delayed closure of the tricuspid valve due to an enlarged anterior leaflet and tricuspid annular dilatation [15]. In cases of severe right ventricular atrialization and right atrial enlargement, jugular venous distension and hepatosplenomegaly may be present, suggestive of right heart failure [13].

\section{Ebstein anomaly and cyanosis}

Eighty percent of patients with Ebstein anomaly have atrial

Table 1. Anatomic classification of Ebstein anomaly [10].

\begin{tabular}{ll}
\hline Anatomic type & Characterization \\
\hline Type I & $\begin{array}{l}\text { Minimal displacement of the tricuspid } \\
\text { valve with an adequate size right ventricle } \\
\text { - }\end{array}$ \\
& $\begin{array}{l}\text { Patients often remain asymptomatic until } \\
\text { adulthood }\end{array}$ \\
\hline Type II & $\begin{array}{l}\text { Marked displacement of the tricuspid valve } \\
\text { and the functional right ventricle is small }\end{array}$ \\
\hline Type III & Anterior leaflet is mobile \\
\hline Type IV & Anterior leaflet is restricted \\
& $\begin{array}{l}\text { Displacement of the tricuspid valve is so } \\
\text { severe that the right ventricle is absent and } \\
\text { the patients present in neonatal life with } \\
\text { cyanosis }\end{array}$ \\
\hline
\end{tabular}

Table 2. Associated anatomical abnormalities in Ebstein anomaly patients.

- Varying degrees of tricuspid regurgitation

- Atrial level communication (patent foramen ovale or atrial septal defect)

- Ventricular septal defect

- Tricuspid stenosis

- Right ventricular outflow tract obstruction

- Mitral valve prolapse

- Bicuspid aortic valve

- Left ventricular abnormalities: Noncompaction cardiomyopathy, systolic and diastolic dysfunction

- Partially anomalous pulmonary venous drainage

- Congenitally corrected transposition of the great arteries (ccTGA) 
Stergiopoulos et al. Cardiovascular System 2015,

septal defect or patent foramen ovale [16,17]. Depending on the severity of tricuspid valve regurgitation and elevation of right heart pressure, the degree of right to left shunt may vary and lead to cyanosis. The clinical spectrum of cyanosis extends from cyanosis present in the neonate, to the presence of cyanosis later in adult life. Potential causes of increases in right to left shunting can be related to exercise or pregnancy. The right to left shunt may result in hypoxemia which does not respond to supplemental oxygen. Erythrocytosis may develop secondary to hypoxia, accounting for a high hematocrit and possibly hyperviscosity syndrome, which can include thrombosis and/or bleeding [18]. However, erythrocytos may not only develop due to secondary hypoxemia related to shunt lesions, but also due to impaired pulmonary perfusion due to TR and RV dysfunction. Erythrocytosis correlates with EA disease severity [18].

\section{Ebstein anomaly and paradoxical emboli}

The presence of interatrial communication in Ebstein anomaly patients poses an increased risk of paradoxical emboli including transient ischemic attack/stroke, brain abscess or myocardial infarction [19]. Percutaneous closure of atrial septal defects or surgical closure may prevent paradoxical emboli [20].

\section{Electrocardiography in ebstein anomaly}

A twelve-lead electrocardiogram (ECG) may demonstrate evidence of right bundle block, right atrial and right ventricular hypertrophy, accessory pathways, "Himalayan" p waves, referring to giant $\mathrm{p}$ waves [21] (Figure 2). Atrial arrhythmias including atrial fibrillation, atrial flutter or atrial tachycardia may be present. Fragmented QRS complex (Figure 2, Arrow) on 12-lead ECG, a marker of myocardial scar, has been associated with larger atrialized RV area and an increased risk of arrhythmic events in adult patients with EA [22].

\section{Ebstein anomaly and arrhythmias}

Patients with EA have the substrate for the development of arrhythmias given the abnormal tricuspid valve, tricuspid valve annulus, and dilatation of the right heart. The presence of pre-excitation accessory pathways including Wolf Parkinson White syndrome, atrial fibrillation, atrial flutter, atrial ectopic tachycardia as well as ventricular tachycardia are common [23]. Rhythm disturbances can be refractory to medical management and radiofrequency ablation may offer better long term durability. However, catheter ablation of accessory pathways remains challenging in this patient population since $50 \%$ of patients have multiple accessory pathways.

\section{Ebstein anomaly and heart failure}

Given the heterogeneity of anatomic variants in Ebstein anomaly, the severity of the valvular and right ventricular dysfunction itself dictates the severity of the clinical presentation. In the adult, worsening tricuspid regurgitation, right and possibly left ventricular dysfunction may lead to worsening right to left shunt and reduced cardiac output. Patients may present with dyspnea, diminished

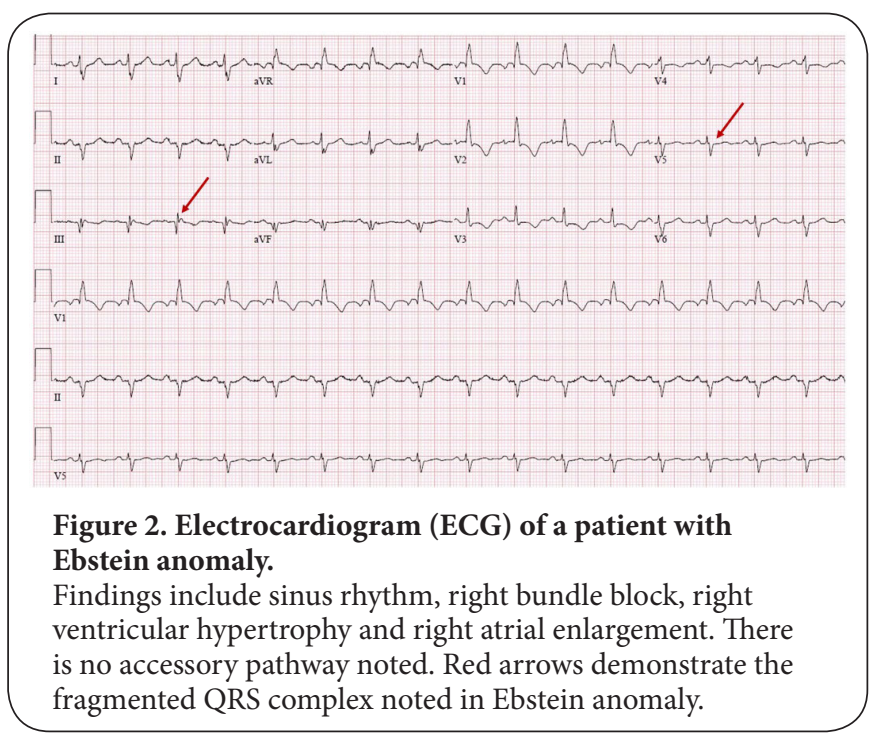

exercise tolerance and fatigue. Patients who have only mild disease may survive until adulthood without having any symptoms [24].

\section{Imaging in ebstein anomaly Echocardiography}

Echocardiography remains the modality of choice for establishing the diagnosis of Ebstein anomaly. Evaluation of the tricuspid valve anatomy is performed from the apical four chamber view from which all four chambers, both atrioventricular valves and interventricular and interatrial septa are visualized (Figure 3). The ratio of the area of the right atrium and atrialized right ventricle to the area of the functional right ventricle and left atrium and left ventricle described by Celermajer has been used to predict prognosis in neonates with a ratio $<0.5$ indicative of grade I and $0 \%$ of death and ratio $>1.5$ grade IV and $100 \%$ of death [25]. The measured distance between the insertion sites of the mitral and tricuspid valve of more than 8 millimeter per square root body surface area is essential for diagnosis. The anterior leaflet can be redundant and elongated and lead to right ventricular outflow tract obstruction. It may have fenestrations and prolapse may be present. Tethering of the leaflets may be present and lead to decreased leaflet mobility. In 2007, Castellanos et al., meticulously described the degrees of leaflet tethering [26]. Increases in right heart volume and dimensions may be present with possible interventricular septum displacement to the left heart a result of right ventricular overload [27]. The left ventricle may be altered as well, with a decrease in left end diastolic volume. Aneurysmal dilation of the right ventricle, defined as an RV diameter twice the aortic root diameter, may be present due to a thinner and less fibrous right ventricular free wall. Color Doppler demonstrates tricuspid regurgitation which is usually moderate or severe.

\section{Cardiac magnetic resonance (CMR)}

The complexity of the right ventricle does not always allow accurate assessment of the anatomy by echocardiography, 

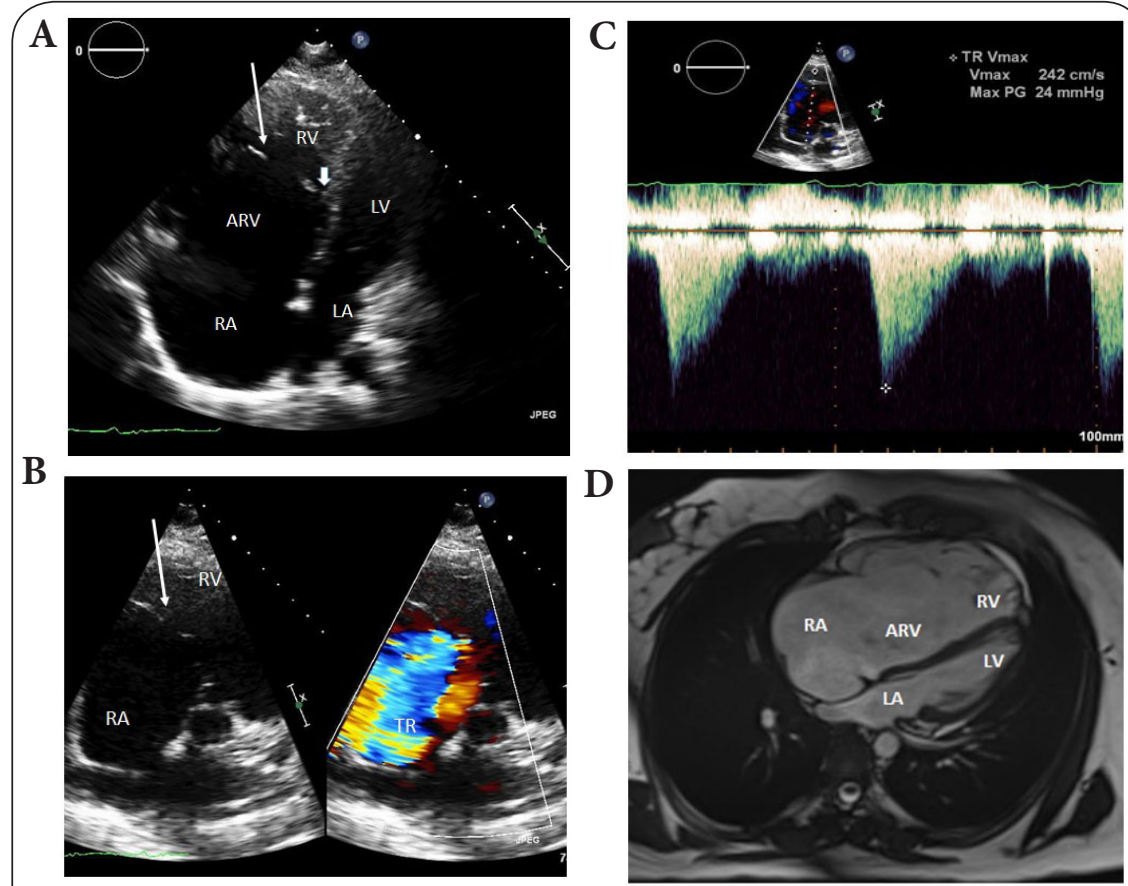

Figure 3. Cardiac imaging of a pregnant woman with ebstein anomaly. A 36 year old woman, without prior pregnancies, originally from Equador, presented for evaluation of a cardiac murmur and palpitations in pregnancy. She complained of NYHA Class II symptoms at prior to pregnancy, worsening to class III during pregnancy. She had no clinical evidence of cyanosis and no pre-excitation on electrocardiography.

Panel A: Apical four chamber view demonstrates severe right atrial (RA) enlargement and severe right ventricular (RV) enlargement, the atrialized right ventricle (ARV), and the apically displaced tricuspid valve (white arrow) consistent with Ebstein anomaly.

Panel B: Demonstrates severe tricuspid regurgitation (TR).

Panel C: Demonstrates a triangular contour of the spectral Doppler of the tricuspid regurgitation, consistent with severe tricuspid regurgitation. The right ventricular systolic pressure, as estimated using the tricuspid regurgitation velocity of $2.27 \mathrm{~m} / \mathrm{s}$ and with an assumed right atrial pressure of $15 \mathrm{mmHg}$, was normal at $35.6 \mathrm{mmHg}$. Color Doppler seen along the interatrial septum was consistent with the presence of a patent foramen ovale or small atrial septal defect(not shown). Fetal cardiac ultrasound performed at 22 weeks was normal (not shown). She was noted to have fetal growth restriction at 37 weeks and was admitted for induction of labor; she was delivered vaginally with an assisted second stage of labor and an epidural without clinical event.

Panel D: Cardiac magnetic resonance imaging (SSFP sequence) performed postpartum demonstrates severely enlarged right ventricular size and severely reduced right ventricular systolic function with a right ventricular ejection fraction of $27 \%$, as well as findings consistent with Ebstein anomaly and severe tricuspid regurgitation. At this time, she was admitted 8 days postpartum for heart failure symptoms. After medical stabilization, she underwent an uncomplicated tricuspid valve replacement with a bioprosthesis.

particularly in the setting of poor acoustic windows. Cardiac magnetic resonance (CMR) has emerged as an imaging modality for patients with Ebstein anomaly [28,29]. In 2011, Yalonetsky et al., demonstrated the reproducibility of right heart measurements [30]. Accurate measurement of right ventricular systolic function (with a right ventricular ejection fraction) is reliable since accurate delineation of right ventricular walls is possible. More recently,
Hösch et al., [31] demonstrate using the easily acquired index of right sided to left sided heart volumes from CMR correlated well with established heart failure markers. CMR, in combination with echocardiography, can provide important complementary information since it can better define the posterior tricuspid leaflet and the presence of fenestrations. Echocardiography is more sensitive for small atrial or ventricular septal defects [32]. 
In addition, MRI is more sensitive for identification of adhesions of the anterior valve and for the assessment of RV function, an important feature in the decision making for surgery as well as for for surgical planning [32] (Figure 3).

\section{Exercise stress testing and physical activity recommendations}

Heart failure symptoms and deterioration of exercise capacity dictate the timing and necessity of surgical intervention in Ebstein patients. Ebstein patients may complain of minimal symptoms; however, they may limit themselves secondary to unrecognized significant functional decline. Exercise stress testing (serially) has been proposed by the 2008 American College of Cardiology/American Heart Association (ACC/ AHA) guidelines for the management of adults with congenital heart disease to be included in the assessment of that patient population [33]. Exercise treadmill protocols which include electrocardiographic monitoring as well as the measurement of peak oxygen consumption (peak VO2), carbon dioxide production, slope of minute ventilation in relation to the carbon dioxide, forced vital capacity and forced expiratory volume in one second have been studied in Ebstein patients [34-36]. Peak VO2 is depressed in the Ebstein population particularly in those with higher "Ebstein Severity Grade" (defined as the ratio of the area of the right atrium and atrialized right ventricle to the area of the functional right ventricle and left atrium and left ventricle [34]) has been identified as a significant predictor of outcome. A level of less than $60 \%$ is associated with higher risk of death, non-elective hospitalization and surgical repair [36]. In the adult Ebstein population, the decline of peak VO2 on follow up cardiopulmonary tests was gradual over the years and the deterioration is attributed to the progressive chronotropic insufficiency and the gradual failure of the right ventricle secondary to chronic volume overload in combination with the worsening tricuspid valve insufficiency [34]. More recently however, Hösch et al., [31] have shown that the Total right/left volume index should be used as a new and simplified CMR measure, allowing more accurate assessment of disease severity than previously described.

\section{Surgical treatment options}

Based on the 2008 ACC/AHA adult congenital heart disease guidelines [33] surgical repair of Ebstein anomaly is indicated in a symptomatic patient, the presence of right ventricular dilation or reduction of systolic function, presence of cyanosis, paradoxical emboli and progressive cardiomegaly on chest $\mathrm{X}$-ray (Figure 4). Repair of the tricuspid valve is preferred over replacement since has been shown to have excellent outcomes in appropriately selected patients, although it remains technically challenging [37]. Surgeons with training and expertise in congenital heart disease should be chosen to operate on patients with Ebstein anomaly. The goal of surgical intervention is to improve functional status and reduce the risk of further right heart enlargement, heart failure and arrhythmias. When replacement is necessary,a bioprosthetic valve is preferred over mechanical valve [38]. Mechanical valve at the tricuspid position in the setting of annular dilation and RV dysfunction predisposes to thrombosis. In choosing a bioprosthetic valve, a porcine valve is often favored over pericardial valve, though reasonable outcomes have been described with the later [39]. The diversity of anatomical variation and age of diagnosis dictate the surgical options. In the adult population, surgery usually involves tricuspid valve repair or replacement, closure of any interatrial communication, arrhythmia treatment, plication of right ventricle and atrial reduction $[10,40,41]$. Furthermore, early repair before signs of cardiomegaly or right heart failure is associated with better outcomes [42].

Adolescent and adult patients with EA undergoing tricuspid valve replacement or repair and concomitant cavopulmonary shunt, created to reduce the preload on the right ventricle, are at risk for early and mid-term complications [43]. However, Ebstein surgery along with cavopulmonary shunt appears to be a reasonable surgical strategy in patients not thought to be suitable for tricuspid valve surgery alone. Quinonez et al., [44] report that a 1.5 -ventricle repair can be utilized in patients with severe Ebstein anomaly and impaired right ventricular function who are at risk for surgical treatment. Moreover, Raju et al., [45] contend that concomitant bidirectional cavopulmonary shunt can be a useful adjunct in repair of advanced EA with severe $\mathrm{RV}$ dilatation and dysfunction.

\section{Management and medical therapy}

A summary of the major points in management and medical therapy are summarized on Table 3.

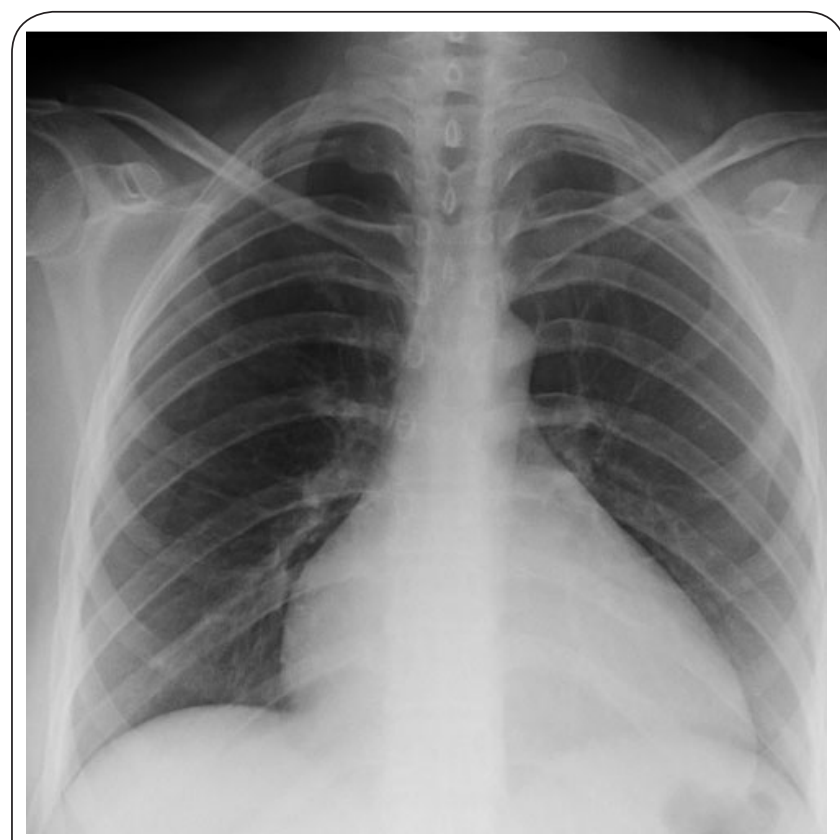

Figure 4. Chest X-ray of a patient with Ebstein anomaly. Findings demonstrating enlargement of the cardiac silhouette. 
Stergiopoulos et al. Cardiovascular System 2015,

http://www.hoajonline.com/journals/pdf/2052-4358-3-7.pdf

doi: $10.7243 / 2052-4358-3-7$

Table 3. Management in adult Ebstein anomaly patients.

- Diuretics for treatment of peripheral edema and right heart failure

- Consider surgical intervention

- Monitor for arrhythmias

- Anticoagulation with warfarin for paradoxical embolus or atrial arrhythmias

- Antibiotic prophylaxis before dental procedures is reasonable in cyanotic patients and postoperative patients with a prosthetic valve

- Routine follow up with a specialist in adult congenital heart disease

- Counseling in women of childbearing potential regarding risks of pregnancy

*Antibiotic prophylaxis is usually not necessary in the unoperated, acyanotic patient.

\section{Prognosis}

Patients with Ebstein anomaly may present with initial symptoms at different stages of life. Generally, those that present later often have more positive outcomes than those presenting in early life. Patients presenting during fetal development, neonates, and infants frequently have severe tricuspid valve distortions with right ventricular deformities causing serious hemodynamic compromises and a negative prognosis. Often these patients encounter complications of heart failure and intrauterine cardiomegaly that causes under development of the lung tissue, repeatedly resulting in fetal demise or sudden infant death [24]. Whereas those patients presenting later in childhood, adolescents, or as adults often have complications of arrhythmias associated with pre-excitation or atrial dilation [24].

Patients undergoing surgical intervention frequently have significant improvements in outcomes. This is noted especially with those undergoing primary tricuspid bioprosthesis, with ten year survival rates over $90 \%$, a good quality of life with $92 \%$ New York Heart Association class I or II and 94\% not receiving anticoagulation [46].

A risk stratification scoring system for patients with adult congenital heart disease has been considered as a means to predict prognosis among patients with Ebstein anomaly. The Seattle Heart Failure Model which was trialed by Stefanescu et al., [47] as a means to differentiate those at high vs. low risk for cardiac complication and death, and has shown evidence of predicting complications. Among patients marked as high risk based on their Seattle Heart Failure Model score, Kaplan-Meier survival analysis has shown greater probability of cardiovascular death [47].

\section{Special issues: pregnancy}

Most patients with Ebstein anomaly will survive until reproductive age and often desire pregnancy. During pregnancy, increased metabolic needs driven by the need of adequate blood supply to the mother and the fetus, lead to dramatic physiologic changes of the maternal cardiovascular system. Marked increases in blood volume, of approximately 50\% compared with the pre-gestation period [48], result in marked hypervolemia. Coincident with that, heart rate and stroke volume increase, accounting for a marked increase in cardiac output. Pregnancy exacerbates baseline abnormalities in RV dilatation and function, which can have deleterious effects on their ability to accommodate the increased blood volume. Careful planning of labor and delivery and avoidance of massive fluid overload can often prevent the consequences of hemodynamic stress. Patients with Ebstein anomaly during labor are at increased risk of developing atrial arrhythmias in the setting of increased catecholamine levels secondary to stress, pain and anxiety. The decrease of peripheral vascular resistance and the increase in pulmonary vascular resistance may increase a right-to-left shunt if present. Fluid shifts may not be well tolerated especially in women with compromised right ventricular systolic function and severe tricuspid regurgitation. The main principles of successful delivery in patients with Ebstein anomaly are to avoid cyanosis, heart failure and arrhythmias. Vaginal delivery is often preferred since has been shown to be safe [49-51].

\section{Pre-conception counseling}

As with other cardiac lesions, patients with Ebstein anomaly require a thorough pre-conception evaluation and counseling in order identify those women at the highest risk. Assessment of New York Heart Association functional class is necessary and physical examination focused on the possible presence of cyanosis, right heart dysfunction, jugular venous distention, parasternal impulse or systolic thrill at the tricuspid valve area, presence of systolic murmur from tricuspid regurgitation and hepatomegaly are essential. Eliciting a history of paradoxical emboli, arrhythmia or heart failure prior to pregnancy are essential for risk stratification. A pre-pregnancy twelve-lead electro cardiogram and echocardiography are essential components of decision-making prior to the initiation of pregnancy.

\section{Systematic review of pregnancy outcomes in Ebstein anomaly}

A systematic review of the literature was performed using the PubMed, Medline and Science Direct databases. Advanced search was used with the words: Ebstein anomaly and pregnancy. Predefined limits were 1) publication after January 1, 1985 for reasons of contemporary applicability; 2) the main body of the text in English, in order to avoid misinterpretation; 3) reviews and case reports ( $<$ or $=2$ pregnancies) were excluded; and 4 ) number of pregnancies completed; 5) complications included adverse maternal cardiovascular and fetal outcomes (mandatory were number of pregnancies, maternal death, heart failure and arrhythmia), and if available embolic event and pre-eclampsia/ eclampsia; and 6) neonatal adverse events recorded included preterm labor, preterm delivery, death, respiratory failure and intracranial hemorrhage (were recorded if available, but not mandatory for inclusion). The search was completed independently by two separate authors (KS and PKS). 
Stergiopoulos et al. Cardiovascular System 2015,

The literature search was performed between December 1, 2014 and January 30, 2015. Systematic literature retrieved a total of 146 publications. Of these, 7 different, retrospective publications were available for review (Table 4). A total of 208 pregnancies were recorded. There were no maternal deaths reported. The number of miscarriages and live births was less well documented. Fetal events were also less well documented. Heart failure complicated 10 pregnancies (4.8\%), while arrhythmia complicated 15 pregnancies (7.2\%). Preterm labor and delivery were common (15.8\% of pregnancies). There were 5 reported cases of neonatal death, 2 fetal intracranial bleeds, and 12 fetuses with low birth weight.

\section{Pregnancy outcomes in Ebstein anomaly}

Sparse literature data exists on pregnancy outcomes in women with Ebstein anomaly. In one of the largest series to date, Donnelly et al., studied forty two pregnancies in twelve women with Ebstein anomaly [50]; the majority were uneventful pregnancies with 36 live births. Most of them underwent vaginal delivery; only two of had complications including significant arrhythmias, cyanosis, and heart failure.In the largest study to date, Connolly et al., studied 44 women, with 111 pregnancies [49]. There were no serious pregnancy-related maternal complications including death, stroke, heart failure or arrhythmias. The majority delivered vaginally ( $89 \%$ versus $11 \%$ who delivered via Cesarean section). A retrospective study studied pregnancy outcomes in cyanotic congenital heart disease patient, including some with Ebstein anomaly [52]. Women with cyanotic congenital heart disease have higher incidence of miscarriage premature births and low birth weights [52]. Overall, pregnancy appears to be well tolerated in most women; however, there was an increased risk of prematurity, fetal loss and fetal congenital heart disease.

\section{Guidelines for pregnancy and Ebstein anomaly}

The American College of Cardiology/American Heart Association Guidelines for Adults with Congenital Heart Disease (CHD) recommends that women with Ebstein anomaly should undertake pre-pregnancy counseling with a physician expert in adult CHD [33]. Most women have a successful pregnancy with appropriate care but there is a risk of low birth weight and fetal loss if significant cyanosis is present. Similarly, the Canadian Cardiovascular Society consensus on the management of adults with CHD suggests in the absence of cyanosis, right heart failure or arrhythmias, pregnancy is well tolerated [53]. To this end, close follow up is warranted during pregnancy, at least once a trimester. Repeat echocardiogram may be necessary to evaluate right ventricular function, as well as possible increase of right to left shunt and severity of tricuspid regurgitation. Medical management may include gentle diuresis if heart failure develops, management of arrhythmias and anticoagulation if indicated such as in patients with atrial fibrillation or history of paradoxical emboli.

\section{Conclusions}

Ebstein anomaly is a rare cardiac congenital disease which is mainly characterized by diversity in the anatomy and the clinical presentation. Diagnosis is made based on the history, clinical findings, electrocardiogram and imaging including echocardiogram and a cardiac MRI. Treatment depends on the age of patient at the time of presentation, the severity of the symptoms and the degree of right ventricular distortion. It ranges from medical management to surgical procedures including tricuspid

Table 4. Systematic literature of the review. Pregnancy outcomes and Ebstein anomaly.

\begin{tabular}{|c|c|c|c|c|c|c|c|c|c|c|c|}
\hline Article & Women & Pregnancies & $\begin{array}{l}\text { Live } \\
\text { Births }\end{array}$ & Miscarriages & $\begin{array}{l}\text { Maternal } \\
\text { Death }\end{array}$ & $\begin{array}{l}\text { Heart } \\
\text { Failure }\end{array}$ & Arrhythmia & $\begin{array}{l}\text { Preterm } \\
\text { Labor \& } \\
\text { Delivery }\end{array}$ & $\begin{array}{l}\text { Neonatal } \\
\text { Death }\end{array}$ & $\begin{array}{l}\text { Intracranial } \\
\text { Hemorrhage }\end{array}$ & $\begin{array}{l}\text { Low } \\
\text { Birth } \\
\text { Weight }\end{array}$ \\
\hline $\begin{array}{l}\text { Donnelly } \\
\text { et al., [50] }\end{array}$ & 12 & 42 & 36 & 5 & 0 & 1 & 2 & 5 & 1 & 0 & 6 \\
\hline $\begin{array}{l}\text { Connolly } \\
\text { et al., [49] }\end{array}$ & 44 & 111 & 85 & 16 & 0 & 0 & 0 & 23 & 2 & 0 & NR \\
\hline $\begin{array}{l}\text { Siu et al., } \\
{[54]}\end{array}$ & NR & 4 & NR & NR & 0 & 1 & 2 & NR & NR & NR & 1 \\
\hline $\begin{array}{l}\text { Siu et al., } \\
{[55]}\end{array}$ & NR & 12 & NR & NR & 0 & 1 & 2 & NR & NR & 0 & NR \\
\hline $\begin{array}{l}\text { Chopra } \\
\text { et al., [56] }\end{array}$ & 4 & 8 & 8 & 0 & 0 & 1 & 2 & 2 & 1 & 0 & 2 \\
\hline $\begin{array}{l}\text { Zhao } \\
\text { et al., [57] }\end{array}$ & 4 & 4 & 4 & 0 & 0 & 0 & 2 & 1 & 0 & 1 & 0 \\
\hline $\begin{array}{l}\text { Katsuragi } \\
\text { et al., [58] }\end{array}$ & 13 & 27 & 21 & 6 & 0 & 6 & 5 & 2 & 1 & 1 & 3 \\
\hline Total & 77 & 208 & 154 & 27 & 0 & 10 & 15 & 33 & 5 & 2 & 12 \\
\hline
\end{tabular}

NR: Not reported 
repair or replacement, and possibly plication of the right ventricle. Appropriate management and follow up of this patient population is mandatory in order to achieve excellent patient outcomes. Even though pregnancy is generally well tolerated in the absence of right heart failure, cyanosis and significant arrhythmias, an individualized approach to the care of pregnant women is essential with follow up with a multidisciplinary team.

\section{Competing interests}

The authors declare that they have no competing interests.

\section{Authors' contributions}

Paraskevi Koutrolou-Sotiropoulou: Data acquisition, data analysis, interpretation of data, drafting of the manuscript, revision of the manuscript Fabio V. Lima: Data acquisition, data analysis, interpretation of data, drafting of the manuscript, revision of the manuscript Anjali Kapur: Drafting of the manuscript, revision of the manuscript Kathleen Stergiopoulos: Data acquisition, data analysis, interpretation of data, drafting of the manuscript, revision of the manuscript.

\section{Acknowledgement}

We gratefully acknowledge Dr Muzammil Musani for providing the cardiac magnetic resonance images for this paper.

\section{Publication history}

Editors: Shih Ann Chen, National Yang Ming University, Taiwan. Osmar Antonio Centurión, National University of Asunción, Paraguay. Received: 01 October 2015 Revised: 02 November 2015 Accepted: 16 November 2015 Published: 26 November 2015

\section{References}

1. Mann RJ and Lie JT. The life story of Wilhelm Ebstein (1836-1912) and his almost overlooked description of a congenital heart disease. Mayo Clin Proc. 1979; 54:197-204. | PubMed

2. Correa-Villasenor A, Ferencz C, Neill CA, Wilson PD and Boughman $J A$. Ebstein's malformation of the tricuspid valve: genetic and environmental factors. The Baltimore-Washington Infant Study Group Teratology. 1994; 50:137-47. | Article | PubMed

3. Lupo PJ, Langlois PH and Mitchell LE. Epidemiology of Ebstein anomaly: prevalence and patterns in Texas, 1999-2005. Am J Med Genet A. 2011; 155A:1007-14. | Article | PubMed

4. Balaji S, Dennis NR and Keeton BR. Familial Ebstein's anomaly: a report of six cases in two generations associated with mild skeletal abnormalities. Br Heart J. 1991; 66:26-8. | Article | PubMed Abstract | PubMed FullText

5. Anderson KR, Zuberbuhler JR, Anderson RH, Becker AE and Lie JT. Morphologic spectrum of Ebstein's anomaly of the heart: a review. Mayo Clin Proc. 1979; 54:174-80. I PubMed

6. Postma AV, van Engelen K, van de Meerakker J, Rahman T, Probst S, Baars MJ, Bauer U, Pickardt T, Sperling SR, Berger F, Moorman AF, Mulder BJ, Thierfelder L, Keavney B, Goodship J and Klaassen S. Mutations in the sarcomere gene MYH7 in Ebstein anomaly. Circ Cardiovasc Genet. 2011; 4:43-50. | Article | PubMed

7. Lamers WH, Viragh S, Wessels A, Moorman AF and Anderson RH. Formation of the tricuspid valve in the human heart. Circulation. 1995; 91:111-21. | PubMed

8. Fratz S, Janello C, Muller D, Seligmann M, Meierhofer C, Schuster T, Schreiber C, Martinoff S, Hess J, Kuhn A, Vogt M and Stern H. The functional right ventricle and tricuspid regurgitation in Ebstein's anomaly. Int J Cardiol. 2013; 167:258-61. | Article | PubMed

9. Dearani JBE and Silva JP. Cone Reconstruction of the Tricuspid Valve for
Ebstein's Anomaly: Anatomic Repair. Operative Techniques in Thoracic and Cardiovascular Surgery. 2008; 13:109-125. | Article

10. Carpentier A, Chauvaud S, Mace L, Relland J, Mihaileanu S, Marino JP, Abry B and Guibourt P. A new reconstructive operation for Ebstein's anomaly of the tricuspid valve. J Thorac Cardiovasc Surg. 1988; 96:92101. | PubMed

11. Goleski PJ, Sheehan FH, Chen SS, Kilner PJ and Gatzoulis MA. The shape and function of the left ventricle in Ebstein's anomaly. Int J Cardiol. 2014; 171:404-12. | Article | PubMed

12. Attenhofer Jost CH, Connolly HM, O'Leary PW, Warnes CA, Tajik AJ and Seward JB. Left heart lesions in patients with Ebstein anomaly. Mayo Clin Proc. 2005; 80:361-8. | Article | PubMed

13. Arya P and Beroukhim R. Ebstein anomaly: assessment, management, and timing of intervention. Curr Treat Options Cardiovasc Med. 2014; 16:338. | Article | PubMed

14. Attie F, Rosas M, Rijlaarsdam M, Buendia A, Zabal C, Kuri J and Granados $\mathrm{N}$. The adult patient with Ebstein anomaly. Outcome in $\mathbf{7 2}$ unoperated patients. Medicine (Baltimore). 2000; 79:27-36. I Article I PubMed

15. Romfh A, Pluchinotta FR, Porayette P, Valente AM and Sanders SP. Congenital Heart Defects in Adults : A Field Guide for Cardiologists. Clin Exp Cardiolog. 2012. | PubMed Abstract | PubMed FullText

16. Brickner ME, Hillis LD and Lange RA. Congenital heart disease in adults. Second of two parts. N Engl J Med. 2000; 342:334-42. | Article | PubMed

17. Brickner ME, Hillis LD and Lange RA. Congenital heart disease in adults. First of two parts. N Engl J Med. 2000; 342:256-63. | Article I PubMed

18. Hosch O, Ngyuen TT, Lauerer P, Schuster A, Kutty S, Staab W, UnterbergBuchwald C, Sohns JM, Paul T, Lotz J and Steinmetz M. BNP and haematological parameters are markers of severity of Ebstein's anomaly: correlation with CMR and cardiopulmonary exercise testing. Eur Heart J Cardiovasc Imaging. 2015; 16:670-5. | Article | PubMed

19. Attenhofer Jost CH, Connolly HM, Scott CG, Burkhart HM, Ammash NM and Dearani JA. Increased risk of possible paradoxical embolic events in adults with ebstein anomaly and severe tricuspid regurgitation. Congenit Heart Dis. 2014; 9:30-7. | Article | PubMed

20. Silva M, Teixeira A, Menezes I, Nogueira G, Ferreira R, Maymone-Martins $\mathrm{F}$ and Anjos R. Percutaneous closure of atrial right-to-left shunt in patients with Ebstein's anomaly of the tricuspid valve. Eurolntervention. 2012; 8:94-7. | Article | PubMed

21. Sharma V, Sharma A and Kumar V. Himalayan P waves. Intern Emerg Med. 2011; 6:81-2. | Article | PubMed

22. Park SJ, Chung S, On YK, Kim JS, Yang JH, Jun TG, Jang SY, Lee OJ, Song J, Kang IS and Huh J. Fragmented QRS complex in adult patients with Ebstein anomaly and its association with arrhythmic risk and the severity of the anomaly. Circ Arrhythm Electrophysiol. 2013; 6:1148-55. | Article | PubMed

23. Hebe J. Ebstein's anomaly in adults. Arrhythmias: diagnosis and therapeutic approach. Thorac Cardiovasc Surg. 2000; 48:214-9. | Article | PubMed

24. Celermajer DS, Bull C, Till JA, Cullen S, Vassillikos VP, Sullivan ID, Allan L, Nihoyannopoulos P, Somerville J and Deanfield JE. Ebstein's anomaly: presentation and outcome from fetus to adult. J Am Coll Cardiol. 1994; 23:170-6. | Article | PubMed

25. Shiina A, Seward JB, Edwards WD, Hagler DJ and Tajik AJ. Twodimensional echocardiographic spectrum of Ebstein's anomaly: detailed anatomic assessment. J Am Coll Cardiol. 1984; 3:356-70. | Article | PubMed

26. Munoz-Castellanos L, Espinola-Zavaleta N, Kuri-Nivon M and Keirns C. Ebstein's Anomaly: anatomo-echocardiographic correlation. Cardiovasc Ultrasound. 2007; 5:43. | Article | PubMed Abstract | PubMed FullText

27. Oechslin E, Buchholz S and Jenni R. Ebstein's anomaly in adults: Dopplerechocardiographic evaluation. Thorac Cardiovasc Surg. 2000; 48:209-13. | Article | PubMed

28. Geva T. Is MRI the preferred method for evaluating right ventricular 
Stergiopoulos et al. Cardiovascular System 2015,

size and function in patients with congenital heart disease?: MRI is the preferred method for evaluating right ventricular size and function in patients with congenital heart disease. Circ Cardiovasc Imaging. 2014; 7:190-7. | Article | PubMed Abstract | PubMed FullText

29. Bonello $B$ and Kilner PJ. Review of the role of cardiovascular magnetic resonance in congenital heart disease, with a focus on right ventricle assessment. Arch Cardiovasc Dis. 2012; 105:605-13. | Article | PubMed

30. Yalonetsky S, Tobler D, Greutmann M, Crean AM, Wintersperger BJ, Nguyen ET, Oechslin EN, Silversides CK and Wald RM. Cardiac magnetic resonance imaging and the assessment of ebstein anomaly in adults. Am J Cardiol. 2011; 107:767-73. I Article I PubMed

31. Hosch O, Sohns JM, Nguyen TT, Lauerer P, Rosenberg C, Kowallick JT, Kutty S, Unterberg C, Schuster A, Fasshauer M, Staab W, Paul T, Lotz J and Steinmetz $\mathrm{M}$. The total right/left-volume index: a new and simplified cardiac magnetic resonance measure to evaluate the severity of Ebstein anomaly of the tricuspid valve: a comparison with heart failure markers from various modalities. Circ Cardiovasc Imaging. 2014; 7:601-9. | Article | PubMed

32. Attenhofer Jost CH, Edmister WD, Julsrud PR, Dearani JA, Savas Tepe M, Warnes CA, Scott CG, Anavekar NS, Ammash NM and Connolly HM. Prospective comparison of echocardiography versus cardiac magnetic resonance imaging in patients with Ebstein's anomaly. Int J Cardiovasc Imaging. 2012; 28:1147-59. | Article | PubMed

33. Warnes CA, Williams RG, Bashore TM, Child JS, Connolly HM, Dearani JA, Del Nido P, Fasules JW, Graham TP, Jr., Hijazi ZM, Hunt SA, King ME, Landzberg MJ, Miner PD, Radford MJ, Walsh EP and Webb GD. ACC/AHA 2008 guidelines for the management of adults with congenital heart disease: a report of the American College of Cardiology/American Heart Association Task Force on Practice Guidelines (Writing Committee to Develop Guidelines on the Management of Adults With Congenital Heart Disease). Developed in Collaboration With the American Society of Echocardiography, Heart Rhythm Society, International Society for Adult Congenital Heart Disease, Society for Cardiovascular Angiography and Interventions, and Society of Thoracic Surgeons. J Am Coll Cardiol. 2008; 52:e143-e263. | Article | PubMed

34. Kipps AK, Graham DA, Lewis E, Marx GR, Banka P and Rhodes J. Natural history of exercise function in patients with Ebstein anomaly: A serial study. Am Heart J. 2012; 163:486-91. | Article | PubMed

35. Trojnarska O, Gwizdala A, Katarzynski S, Katarzynska A, Szyszka A, Lanocha M, Grajek S and Kramer L. Evaluation of exercise capacity with cardiopulmonary exercise test and B-type natriuretic peptide in adults with congenital heart disease. Cardiol J. 2009; 16:133-41. | Article | PubMed

36. Radojevic J, Inuzuka R, Alonso-Gonzalez R, Borgia F, Giannakoulas G, Prapa M, Liodakis E, Li W, Swan L, Diller GP, Dimopoulos K and Gatzoulis MA. Peak oxygen uptake correlates with disease severity and predicts outcome in adult patients with Ebstein's anomaly of the tricuspid valve. Int J Cardiol. 2013; 163:305-308. | Article | PubMed

37. Vargas FJ, Mengo G, Granja MA, Gentile JA, Rannzini ME and Vazquez JC. Tricuspid annuloplasty and ventricular plication for Ebstein's malformation. Ann Thorac Surg. 1998; 65:1755-7. | Article | PubMed

38. Brown ML, Dearani JA, Danielson GK, Cetta F, Connolly HM, Warnes CA, Li Z, Hodge DO and Driscoll DJ. Comparison of the outcome of porcine bioprosthetic versus mechanical prosthetic replacement of the tricuspid valve in the Ebstein anomaly. Am J Cardiol. 2009; 103:555-61. | Article I PubMed

39. Sha JM, Yan ZY, Zhu ZY, Tan L, Zheng L, Shen YH, Lu Z, Wu YJ, Sun Y and Cheng GC. Early and midterm results of repair of Ebstein's anomaly with autologous pericardium. Thorac Cardiovasc Surg. 2011; 59:287-92. | Article | PubMed

40. Danielson GK, Driscoll DJ, Mair DD, Warnes CA and Oliver WC, Jr. Operative treatment of Ebstein's anomaly. J Thorac Cardiovasc Surg. 1992; 104:1195-202. | PubMed

41. Davies RR, Pasquali SK, Jacobs ML, Jacobs JJ, Wallace AS and Pizarro C. Current spectrum of surgical procedures performed for Ebstein's malformation: an analysis of the Society of Thoracic Surgeons
Congenital Heart Surgery Database. Ann Thorac Surg. 2013; 96:1703-9. I Article | PubMed Abstract | PubMed FullText

42. Badiu CC, Schreiber C, Horer J, Ruzicka DJ, Wottke M, Cleuziou J, Krane $M$ and Lange R. Early timing of surgical intervention in patients with Ebstein's anomaly predicts superior long-term outcome. Eur J Cardiothorac Surg. 2010; 37:186-92. | Article | PubMed

43. Al-Najashi KS, Balint OH, Oechslin E, Williams WG and Silversides CK. Mid-term outcomes in adults with ebstein anomaly and cavopulmonary shunts. Ann Thorac Surg. 2009; 88:131-6. | Article | PubMed

44. Quinonez LG, Dearani JA, Puga FJ, O'Leary PW, Driscoll DJ, Connolly $\mathrm{HM}$ and Danielson GK. Results of the 1.5-ventricle repair for Ebstein anomaly and the failing right ventricle. J Thorac Cardiovasc Surg. 2007; 133:1303-10. | Article | PubMed

45. Raju V, Dearani JA, Burkhart HM, Grogan M, Phillips SD, Ammash N, Pike $\mathrm{RP}$, Johnson JN and O'Leary PW. Right ventricular unloading for heart failure related to Ebstein malformation. Ann Thorac Surg. 2014; 98:16773. | Article | PubMed

46. Augustin N, Schmidt-Habelmann P, Wottke M, Meisner $H$ and Sebening F. Results after surgical repair of Ebstein's anomaly. Ann Thorac Surg. 1997; 63:1650-6. | Article | PubMed

47. Stefanescu A, Macklin EA, Lin E, Dudzinski DM, Johnson J, Kennedy KF, Jacoby D, DeFaria Yeh D, Lewis GD, Yeh RW, Liberthson R, Lui G and Bhatt AB. Usefulness of the Seattle Heart Failure Model to identify adults with congenital heart disease at high risk of poor outcome. Am J Cardiol. 2014; 113:865-70. | Article | PubMed

48. Silversides CK CJ. Physiologic changes in pregnancy. In: Oakley C, Warnes CA, editors. Heart Disease in Pregnancy. Malden, MA: Blackwell Publishing. 2007; 173-85.

49. Connolly HM and Warnes CA. Ebstein's anomaly: outcome of pregnancy. J Am Coll Cardiol. 1994; 23:1194-8. | Article | PubMed

50. Donnelly JE, Brown JM and Radford DJ. Pregnancy outcome and Ebstein's anomaly. Br Heart J. 1991; 66:368-71. | Article | PubMed Abstract | PubMed FullText

51. Regitz-Zagrosek V, Blomstrom Lundqvist C, Borghi C, Cifkova R, Ferreira R, Foidart JM, Gibbs JS, Gohlke-Baerwolf C, Gorenek B, lung B, Kirby M, Maas AH, Morais J, Nihoyannopoulos P, Pieper PG, Presbitero P, Roos-Hesselink JW, Schaufelberger M, Seeland U and Torracca L. ESC Guidelines on the management of cardiovascular diseases during pregnancy: the Task Force on the Management of Cardiovascular Diseases during Pregnancy of the European Society of Cardiology (ESC). Eur Heart J. 2011; 32:3147-97. | Article | PubMed

52. Presbitero P, Somerville J, Stone S, Aruta E, Spiegelhalter D and Rabajoli F. Pregnancy in cyanotic congenital heart disease. Outcome of mother and fetus. Circulation. 1994; 89:2673-6. | PubMed

53. Silversides CK, Salehian O, Oechslin E, Schwerzmann M, Vonder Muhll I, Khairy P, Horlick E, Landzberg M, Meijboom F, Warnes C and Therrien J. Canadian Cardiovascular Society 2009 Consensus Conference on the management of adults with congenital heart disease: complex congenital cardiac lesions. Can J Cardiol. 2010; 26:e98-117. | Pdf | PubMed Abstract | PubMed FullText

54. Siu SC, Sermer M, Harrison DA, Grigoriadis E, Liu G, Sorensen S, Smallhorn JF, Farine D, Amankwah KS, Spears JC and Colman JM. Risk and predictors for pregnancy-related complications in women with heart disease. Circulation. 1997; 96:2789-94. | PubMed

55. Siu SC, Sermer M, Colman JM, Alvarez AN, Mercier LA, Morton BC, Kells CM, Bergin ML, Kiess MC, Marcotte F, Taylor DA, Gordon EP, Spears JC, Tam JW, Amankwah KS, Smallhorn JF, Farine D and Sorensen S. Prospective multicenter study of pregnancy outcomes in women with heart disease. Circulation. 2001; 104:515-21. | PubMed

56. Chopra S, Suri V, Aggarwal N, Rohilla M, Vijayvergiya R and Keepanasseril A. Ebstein's anomaly in pregnancy: maternal and neonatal outcomes. $J$ Obstet Gynaecol Res. 2010; 36:278-83. | Article | PubMed

57. Zhao W, Liu H, Feng R and Lin J. Pregnancy outcomes in women with Ebstein's anomaly. Arch Gynecol Obstet. 2012; 286:881-8. | Article | PubMed 
Stergiopoulos et al. Cardiovascular System 2015,

http://www.hoajonline.com/journals/pdf/2052-4358-3-7.pdf

58. Katsuragi S, Kamiya C, Yamanaka K, Neki R, Miyoshi T, Iwanaga N, Horiuchi C, Tanaka H, Yoshimatsu J, Niwa K and Ikeda T. Risk factors for maternal and fetal outcome in pregnancy complicated by Ebstein anomaly. Am J Obstet Gynecol. 2013; 209:452 e1-6. | Article I PubMed

59. Warnes CA. Adult congenital heart disease importance of the right ventricle. J Am Coll Cardiol. 2009; 54:1903-10. | Article | PubMed

\section{Citation:}

Koutrolou-Sotiropoulou P, Lima FV, Kapur A and Stergiopoulos K. Ebstein anomaly in the adult: focus on pregnancy. Cardio Vasc Syst. 2015; 3:7.

http://dx.doi.org/10.7243/2052-4358-3-7 